\title{
Drought, freshwater availability and cultural resilience on Easter Island (SE Pacific) during the Little Ice Age
}

\author{
Valentí Rull \\ Institute of Earth Sciences Jaume Almera (ICTJA-CSIC), C. Solé i Sabarís s/n, 08028 Barcelona, Spain. \\ Email:vrull@ictja.csic.es
}

\begin{abstract}
After decades of human-deterministic explanations for the collapse of the ancient Rapanui culture that inhabited Easter Island (Rapa Nui) before European contact (1722 CE), paleoecological studies developed over the last decade have provided sound evidence of climate changes and their potential socioecological impacts. Especially significant is the occurrence of a century-scale drought (1570-1720 CE) during the Little Ice Age (LIA). Freshwater is a critical resource on Easter Island that heavily depends on rain, which maintains the only three permanent surficial freshwater sources on the island: two lakes (Rano Kao and Rano Raraku) and a marsh (Rano Aroi). Under these conditions, the LIA drought could have significantly affected human life; however, the Rapanui society remained healthy, showing remarkable resilience. There are two main hypotheses on how the ancient Rapanui could have obtained freshwater to guarantee their continuity. One of these hypotheses proposes that Lake Kao was a permanent source of freshwater, even during the LIA drought, which led to some intraisland cultural and population reorganizations. The coastal groundwater hypothesis dismisses the use of lakes and other surficial freshwater sources to maintain the water-stressed Rapanui population and contends that the only routine freshwater sources during the LIA drought were the abundant and widespread coastal seeps fed by fresh/brackish groundwater. The pros and cons of these two hypotheses are discussed on the basis of the available archeological and paleoecological evidence, and it is concluded that given the present state of knowledge, neither can be rejected. Therefore, these two proposals could be complementary rather than mutually exclusive.
\end{abstract}

Keywords: Easter Island, Rapa Nui, Little Ice Age, drought, freshwater, brackish water, groundwater, lakes, coastal seeps, cultural change, archeology, paleoecology

\section{Introduction}

Easter Island (Rapa Nui) is a small $\left(\sim 164 \mathrm{~km}^{2}\right)$ and isolated island in the SE Pacific that was formed by the coalescence of three volcanic cones: Kao, Poike and Terevaka (Fig. 1A). The island is famous for its ritual megalithic statues (moai) (Fig. 1B) built by an ancient Polynesian culture that settled the island between $800 \mathrm{CE}$ and $1200 \mathrm{CE}$, with the settlement time depending on the authors (Hunt and Lipo, 2006;

Wilmshurst et al., 2011; Rull, 2019a). This culture is assumed to have caused its own destruction by overexploitation of natural resources prior to European contact (1722 CE) (Flenley and Bahn, 2003; Diamond, 2005). This ecocidal hypothesis largely relies on the apparently abrupt and island-wide deforestation inferred from pollen analysis of lake sediments (Flenley and King, 1984; Flenley et al., 1999). It has also been suggested that rats introduced by Polynesian colonizers contributed to deforestation by extensive eating of palm fruits, thus restraining forest regeneration (Hunt, 2007). Others contend that the collapse of the ancient Rapanui culture was actually a genocide mainly due to postcontact events, such as slave trading and the introduction of alien infectious diseases, which are historically well documented (Métraux, 1957; Peiser, 2005; Hunt, 2007). Both ecocidal and genocidal views are considered human deterministic, as they attribute the collapse of the ancient Rapanui culture exclusively to anthropogenic causes (Rull, 2018). A potential role of climate change in the deforestation and general deterioration of island resources has traditionally been ignored or explicitly dismissed.

During the last decade, increasing paleoecological evidence of climatic shifts has suggested that climate and climate-human feedbacks and synergies could have played a significant role in precontact ecological 
and cultural developments (Rull et al., 2018). Especially significant is the occurrence of some extended droughts during the Medieval Climate Anomaly (MCA) and the Little Ice Age (LIA) before European contact. The LIA arid phase would have been particularly critical as it was coeval with the total deforestation of the island (Rull, 2019b). The absence of surficial streams and springs due to the high permeability of Easter Island's volcanic rocks (Herrera and Custodio, 2008) makes freshwater a critical resource, and this island heavily depends on rainfall to recharge the groundwater system and the only three permanent waterbodies on the island: two lakes (Rano Kao and Rano Raraku) and a marsh (Rano Aroi), all of which are within volcanic craters (Fig. 1A). In addition, contrary to other Polynesian societies (Nunn, 2007), the ancient Rapanui culture did not use irrigation practices for cultivation (Puleston et al., 2017; Hunt \& Lipo, 2011). Under these conditions, the LIA drought, lasting approximately a century and a half, would have had critical impacts on the ecology and culture of the island. However, recent archeological evidence suggests that the Rapanui society not only survived but also remained in good condition until European contact (Mulrooney, 2013; Stevenson et al., 2015; Jarman et al., 2017).

The potential impacts of the LIA drought are still to be ascertained, but several ideas have already been proposed to determine how the ancient Rapanui society successfully circumvented this climatic bottleneck. Recent paleoecological and archeological findings are consistent with intraisland population reorganizations resulting from the search for new freshwater sources (Rull, 2016a; Rull et al., 2018). In contrast, the coastal groundwater hypothesis proposes that freshwater was obtained from coastal groundwater seeps and explicitly dismisses other possibilities (Brosnan et al., 2018; DiNapoli et al., 2019). This paper briefly summarizes these two proposals and aims to show that they may be complementary rather than mutually exclusive.

\section{MCA and LIA droughts}

Independent multiproxy analyses (sedimentology, mineralogy, organic and inorganic geochemistry, pollen, diatoms) of the Raraku lake sediments provided evidence for the occurrence of two phases of arid climates leading to the lake drying out (Fig. 2). This lake was the quarry of the moai during the maximum development of the ancient Rapanui culture. The first of these droughts took place between $500 \mathrm{CE}$ and $1200 \mathrm{CE}$, during the Medieval Climatic Anomaly (MCA), when warm and dry conditions prevailed in the South Pacific basin (Nunn \& Britton, 2001; Nunn, 2007). The time interval proposed by different authors for the Polynesian settlement of the island (800-1200 CE) falls within this arid phase (Rull, 2019a and literature therein). The second drought occurred between $1570 \mathrm{CE}$ and $1720 \mathrm{CE}$, during the Little Ice Age (LIA) and just before European contact (Cañellas-Boltà et al., 2013), and was associated with the occurrence of several drought phases in the Pacific basin during the same period (Nunn, 2000, 2007). Between these two arid phases, a humid period extended from $1200 \mathrm{CE}$ to $1570 \mathrm{CE}$, coinciding with the maximum development of the Rapanui civilization (Fischer, 2005; McCall, 2009) and the socalled "1300 event", a phase of assumed cool and wet Pacific climates (Nunn, 2007). Similar analyses carried out on the Aroi sediments also documented some century-scale dry climatic phases, the first occurring between approximately $300 \mathrm{BCE}$ and $50 \mathrm{CE}$, the second occurring between $600 \mathrm{CE}$ and 1100 $C E$, roughly coinciding with the MCA drought recorded at Raraku, and a third phase that could not be attributed to climatic drought and/or anthropogenic influence (Rull et al., 2015). During this phase, which coincided with the LIA Raraku drought (1570-1720 CE), the Aroi record shows an abrupt deforestation event between 1520 CE and 1620 CE (Fig. 2), which is the last deforestation event recorded on the island (Rull, 2019b). As mentioned above, the total deforestation of the island and the assumed demise of the ancient Rapanui culture took place during the LIA drought. After $1720 \mathrm{CE}$, coinciding with European arrival, climates became wetter again, and Lake Raraku replenished. The Kao record roughly encompasses the last millennium (ca. $900 \mathrm{CE}$ to $1800 \mathrm{CE}$ ), and although the main vegetation trends have already been reported, independent paleoclimatic inferences based on biomarker analysis are still in progress (Seco et al., 2019). However, this paleoecological record is free from sedimentary gaps, which indicates that this lake did not dry out during the last millennium (Rull, 2016b). Lake Kao is the largest (ca. $1200 \mathrm{~m}$ diameter) and deepest (>10 m) waterbody on the island and is less prone to desiccation than the smaller (ca. $300 \mathrm{~m}$ diameter) and shallower (up to $2 \mathrm{~m}$ depth) Lake Raraku. 


\section{Lake Kao as a permanent freshwater source}

The first approach to inferring freshwater availability during the LIA drought was to suggest that Lake Kao would have been the main source of freshwater during this arid phase. This may have resulted in intraisland reorganizations as Lake Raraku, which was the quarry where the moai were carved and the cultural center of the ancient Rapanui civilization during its maximum flourishment (Edwards and Edwards, 2011), was completely dry for approximately a century and a half (1570-1720 CE) and its surroundings were fully and irreversibly deforested by 1450 CE (Rull 2016a). This would have turned the Kao crater (which was still forested) and its freshwater lake into a more important site than it had been previously for the Rapanui society. In support of this hypothesis, there is archaeological, paleoethnobotanical and paleoecological evidence for enhanced human presence near Lake Kao and its surroundings during the LIA drought. One of the more emblematic sites of Easter Island is the ceremonial village of Orongo, situated on the SW crest of the Kao crater (Fig. 3), which was the center of the so-called Birdman cult, which replaced the ancient moai cult and represented a deep social, cultural and religious transformation of the Rapanui society. A compilation of radiocarbon and obsidian hydration dates suggested that Orongo was founded no earlier than $1600 \mathrm{CE}$ and that human activities intensified in the late $18^{\text {th }}$ century (Robinson and Stevenson, 2017). In addition, there is sound evidence of precontact agriculture along the Lake Kao shores, where large-scale deforestation by fire and mixedcrop production (paper mulberry, taro, banana, greater yam) on gardened terraces has been documented (Horrocks et al., 2012, 2013). Most of this evidence of cultivation has been found on the lakeshores immediately below Orongo (Fig. 3), which suggests a possible connection with this relict village. Finally, palynological analyses of Kao sediments showed that the total deforestation of the site occurred by $1610 \mathrm{CE}$ and coincided with conspicuous fire exacerbation and a sharp increase in coprophilous fungi (notably Sporormiella) living on the dung of domestic vertebrates, which are reliable indicators of human presence (Seco et al., 2019). In summary, there is concurrent independent evidence indicating a significant increase in human presence and activities around Lake Kao and its catchment during the LIA drought. This may be linked to the possibility of Lake Kao permanently supplying freshwater for human use and agriculture, even during the driest climatic phases, when other freshwater bodies dried out.

Another potential freshwater source could have been the Rano Aroi marsh, which is situated in the inland Terevaka uplands (Figs. $1 \mathrm{~A}$ and 3 ). It is possible that, owing to the elevational precipitation gradient (Stevenson et al., 2015; Puleston et al., 2017), drought was less intense in these upland areas and this marsh contained freshwater. Human presence is supported by the occurrence of total deforestation by fire between approximately 1550 CE and 1650 CE (Rull et al., 2015) (Fig. 2). However, human presence at Aroi was ephemeral. Indeed, the site was likely abandoned by $1700 \mathrm{CE}$, as indicated by the abrupt decrease in fire (Rull et al., 2015) and the last evidence of cultivation dated to $1670 \mathrm{CE}$ (Horrocks et al., 2015).

\section{Coastal groundwater hypothesis}

A different view has been proposed more recently, according to which fresh/brackish coastal seeps could have been the major source of water for the survival of the ancient Rapanui society during the LIA climatic drought (Brosnan et al., 2018). Such a conclusion is based on the consideration that other potential freshwater sources (permanent lakes, springs, ephemeral streams and pools) would not have been sufficient to support a population of thousands of individuals. According to these authors, the lake of Rano Kao is too difficult to access to have been a routine source of freshwater, and moreover, there is no archeological evidence of human habitation of its shores. Rano Raraku is considered to be a reliable source of freshwater but only for the populations in its immediate surroundings. The same would be true for Rano Aroi, whose spring is unlikely to have been useful to satisfy the needs of the whole island due to its remoteness. Temporary streams and ponds were also considered too ephemeral (lasting hours to a few days after a rain event) for such purposes, and some receptacles used to collect rainwater (taheta) found in archeological sites were too small and too susceptible to water evaporation 
for large-scale human usage (Brosnan et al., 2018). This, together with the absence in the archeological record of large water containers and intense habitation near lakes and marshes, led to the conclusion by these authors that coastal seeps would have been crucial for prehistoric Rapanui subsistence. Hixon et al. (2019) extended this conclusion to postcontact times and argued that coastal seeps were of fundamental importance until the mid- $20^{\text {th }}$ century. In addition to the difficulty of accessing the crater lakes, these authors emphasize the unpalatability of their waters, on the basis of historical accounts.

In the groundwater system, freshwater accumulates on top, and salinity increases with depth due to the diffusion of seawater from below, which creates a vertical density gradient. This groundwater system is shallower on the coasts, where fresh/brackish waters are more accessible and artificial wells are common today (Herrera and Custodio, 2008) (Fig. 4). These coastal wells contain small amounts of freshwater, less than a meter deep, above brackish and marine groundwater (Brosnan et al., 2018). The Rapanui did not have the technology to drill deep wells in volcanic rocks; to capture fresh and brackish waters from coastal seeps, they used pits excavated parallel to the shoreline. The remains of these structures, called puna, have been found at several sites along the island's coasts, which were the preferred sites for the Rapanui to live. Therefore, fresh/brackish water sources would have been frequent, widespread and close to the populated sites (Brosnan et al., 2018). According to DiNapoli et al. (2019), the $a h u$, in addition to their ritual meaning, would have a signaling function to indicate the locations of such coastal seeps. All waters found today in coastal seeps are brackish (ca. 4 to $28 \mathrm{~g}$ of marine salt/L, compared to $1 \mathrm{~g} / \mathrm{L}$ or less for freshwater and $35 \mathrm{~g} / \mathrm{L}$ for seawater), which led Brosnan et al. (2018) to suggest that the Rapanui drank brackish water, a fact that, according to these authors, has been well documented historically.

\section{Discussion}

The assumed uniqueness of coastal seeps as a routine freshwater source for the Rapanui is based on the dismissal of other potential sources (Brosnan et al., 2018; DiNapoli et al., 2019). In the case of Rano Kao, the main arguments for its eventual dismissal as a routine freshwater source are the difficulty of access and the lack of archeological evidence of habitation at the lake margins. Regarding accessibility, it is true that the inner Rano Kao walls are high and steep (Fig. 3) but not impracticable, at all, as it is possible to easily descend to the lake and come back by foot in approximately one hour or less. Modern paleoecologists know this well, and we use this method during sediment-coring campaigns with all the equipment and necessary provisions. The ancient Rapanui demonstrated an outstanding transport capacity by transporting the moai (up to $20 \mathrm{~m}$ high and over 250 tons of weight) from the Rano Raraku quarry to all parts of the island, including elevations above $200 \mathrm{~m}$ (Fig. 1A). Transporting water across the Rano Kao walls is a much easier task that could be conducted on a daily basis. Given the absence of conspicuous water-transporting infrastructures (Puleston et al., 2017; Hunt \& Lipo, 2011), freshwater might have been carried in easily transportable containers such as bottle-gourd (Lagenaria siceraria) fruits, which were intensively cultivated for such purpose across Polynesia, including on Easter Island (Green, 2000; Clarke et al., 2006). Easter Islanders could have easily transported water from Lake Kao in this way. Indeed, practitioners of the Birdman cult were required to descend to the sea, swim to the Motu Nui islet (Fig. 1A), situated $2 \mathrm{~km}$ away from the coast, and return to Orongo via the outer Rano Kao cliffs, which were remarkably higher and more difficult to climb than the inner walls of this crater. Al of this was performed in a single day by Rapanui athletes. Obtaining freshwater from the lake is a much easier task that could be routinely performed by common people, such as paleoecologists. It seems totally unreasonable that Rapanui people would have refused to routinely obtain water from Rano Kao to avoid a barely one-hour trip to the lake shores.

In addition, evidence of precontact agriculture along the Rano Kao shores immediately below Orongo (Fig. 3) suggests a connection with this relict village. There is no evidence of human dwellings on the lake shores, and it is reasonable to assume that the agricultural products were transported to Orongo for human consumption and, eventually, distribution to other places. The same would be true for lake freshwater, whose transport could have been performed in the same way and at the same time. Transporting agricultural products but no freshwater from the Rano Kao shores seems absurd. Given the 
already mentioned outstanding transport capabilities of Rapanui people, distributing agricultural products and water from Orongo to other places would have been very easy.

The main strength of the coastal groundwater hypothesis is that water sources are numerous, widespread and close to the habitation sites. However, there are two main drawbacks in considering this possibility as the only way of obtaining freshwater during the LIA drought. First, this hypothesis was erected after a detailed study of only the eastern half of the island (Fig. 1A), where access is easier. Given the present state of knowledge, this situation cannot be extrapolated to the western sector, which included the center of the Rapanui culture during the LIA drought, where the physiography is very different and coastal seeps have not been reported. Second, all present-day coastal seeps identified in the eastern sector produce brackish water rather than freshwater (Brosnan et al., 2018). If this was the main water source for the ancient Rapanui during the LIA drought, they must have survived for approximately six generations ( 150 years; $1570-1720 \mathrm{CE}$ ) with only brackish water for drinking and agriculture, which would have been challenging, if not hard to believe, and does not seem to be the most efficient (and palatable) solution. Finally, as rain is the only freshwater source for the groundwater system, such a supply should have been drastically reduced during droughts, as discussed here, suggesting that the salinity of coastal seeps could have been higher than it is today. Therefore, coastal seeps could have been used by the ancient Rapanui, but other truly freshwater sources likely would have been needed to maintain this society in good shape.

\section{Final remarks}

In summary, the hypotheses discussed here have advantages and drawbacks, but with the available evidence, neither can be rejected. Therefore, there is no reason to exclude either of these hypotheses to explain freshwater availability during the LIA drought. From a human perspective, it seems reasonable to take advantage of any freshwater sources available during a secular-scale drought such as that during the LIA. Regardless of the strategy adopted, the continuity of the Rapanui culture despite landscape degradation by anthropogenic deforestation and climatic drought is a good example of cultural resilience that challenges former deterministic explanations and emphasizes human adaptability to changing environments. It is hoped that further research will provide new empirical data not only to test the existing hypotheses but also to form new ones, thus providing a clearer picture of how ancient Easter Islanders circumvented the scarcity of freshwater to continue living on the island and developing their culture. Finally, it should be noted that the hypotheses examined in this paper are testable rather than speculative. A simple test would be a long-term experiment involving two human populations and their descendants, one entitled to use all natural freshwater sources available on the island during the LIA drought and the other relying only on brackish coastal seeps for a century and a half. It would be interesting to see whether the defenders of the coastal seep hypothesis would voluntarily enroll in the second group.

\section{Acknowledgments}

The author's Easter Island research was funded by the Spanish Ministry of Education and Science, through projects LAVOLTER (CGL2004-00683) and GEOBILA (CGL2007-60932/BTE). Sample processing and analysis were performed in the Laboratory of Paleoecology, Institute of Earth Sciences Jaume Almera (ICTJA), Higher Spanish Council for Scientific Research (CSIC). Discussions with the team members of these projects are greatly acknowledged, especially those with Núria Cañellas-Boltà, Santiago Giralt, Olga Margalef, Sergi Pla-Rabes and Alberto Sáez. However, the views expressed herein are the solely those of the author. Comments by two anonymous reviewers helped improve the manuscript. 


\section{References}

Brosnan T, Becker MW and Lipo CP (2018) Coastal groundwater discharge and the ancient inhabitants of Rapa Nui (Easter Island), Chile. Hydrogeology Journal 27: 519-534.

Cañellas-Boltà N, Rull V, Sáez A, Margalef O, Bao R, Pla-Rabes S, Blaauw M, Valero-Garcés B and Giralt S (2013) Vegetation changes and human settlement of Easter Island during the last millennia: a multiproxy study of Lake Raraku sediments. Quaternary Science Reviews 72: 36-48.

Clarke AC, Burtenshaw MK, McLenachan PA, Erickson DL, Penny D (2006) Reconstructing the origins and dispersal of the Polynesian bottle gourd (Lagenaria siceraria). Molecular Biology and Evolution 23: 893-900.

Diamond J (2005) Collapse. How societies choose to fail or survive. London: Allen Lane.

DiNapoli RJ, Lipo CP, Brosnan T, Hunt TL, Hixon S, Morrison AE and Becker M (2019) Rapa Nui (Easter Island) monument (ahu) locations explained by freshwater sources. PLOS ONE, 14, doi: 10.137/journal.pone.02010409.

Edwards E and Edwards A (2013) When the universe was an island. Exploring the culrutal and spiritual cosmos of the ancient Rapanui. Hangaroa: Hangaroa Press.

Flenley JR and Bahn PG (2003) The enigmas of Easter Island. Oxford: Oxford University Press.

Flenley JR and King S (1984) Late Quaternary pollen records from Easter Island. Nature 307: 47-50.

Flenley JR, King ASM, Jackson J and Chew C (1991) The Late Quaternary vegetational and climatic history of Easter Island. Journal of Quaternary Science 6: 85-115.

Fischer SR (2005) Island at the end of the world. The turbulent history of Easter Island. Reaktion Books, London.

Green RC (2000) A range of disciplines support a dual origin for the bottle gourd in the Pacific. Journal of the Polynesian Society 109: 191-197.

Herrera C and Custodio E (2008) Conceptual hydrogeological model of volcanic Easter Island (Chile) after chemical and isotopic surveys. Hydrogeology Journal 16: 1329-1348.

Hixon SW, DiNapoli RJ, Lipo CL and Hunt TL (2019) The ethnohistory of freshwater use on Rapa Nui (Easter Island, Chile). Journal of the Polynesian Society 128: 163-189.

Horrocks M, Baisden WT, Nieuwoudt WT, Flenley J, Feek D, González-Nualart L, Haoa-Cardinali S and Edmunds Gorman T (2012) Microfossils of Polynesian cultigen sin lake sediment cores from Rano Kau, Easter Island. Journal of Paleolimnology 47: 185-204.

Horrocks M, Marra M, Baisden WT, Flenley J, Feek D, González-Nualart L, Haoa-Cardinali S and Edmunds Gorman T (2013) Pollen, phytoliths, arthropods and high-resolution ${ }^{14} \mathrm{C}$ sampling from Rano Kau, Easter Island: evidence for late quaternary environments, ant (formicidae) distributions and human activity. Journal of Paleolimnology 50: 417-432.

Hunt TL (2007) Rethinking Easter Island's ecological catastrophe. Journal of Archaeological Science 34: 485-502.

Hunt TL and Lipo CP (2006) Late colonization of Easter Island. Science 311: 1603-1606.

Hunt TL and Lipo CP (2011) The statues that walked. Free Press, New York.

Jarman CL, Larsen T, Hunt T, Lipo C, Solsvik K, Wallsgrove N, Ka'apu-Lyons C, Close HG and Popp BN (2017) Diet of the prehistoric population of Rapa Nui (Easter Island, Chile) shows environmental adaptation and resilience. American Journal of Physical Anthropology 164: 343-361.

McCall G (2009) Easter Island. In Gillespie RG and Clague AD (eds.), Encyclopedia of Islands. Univ California Press, Berkeley, pp. 244-251

Métraux A (1957) Easter Island: A Stone-Age Civilization of the Pacific. London: Andre Deutsch.

Mulrooney M (2013) An island-wide assessment of the chronology of settlement and land use on RapaNui (Easter Island) based on radiocarbon data. Journal of Archaeological Science 40: 43774399.

Nunn PD (2000) Environmental catastrophe in the Pacific Islands around A.D. 1300. Geoarchaeology 15: 715-740.

Nunn PD (2007) Climate, environment and society in the Pacific during the last millennium. Elsevier, Amsterdam.

Nunn PD and Britton JMR (2001) Human-environment relationships in the Pacific Islands around A.D. 1300. Environment and History 7: 3-22. 
Peiser B (2005). From genocide to ecocide, the rape of Rapa Nui. Energy and Environment 16: 513-539.

Puleston CO, Ladefoged TN, Haoa S, Chadwick OA, Vitousek PM and Stevenson CM (2017) Rain, sun, soil, and sweat: a consideration of population limits on Rapa Nui (Easter Island) beofre European contact. Frontiers in Ecology and Evolution 5: 69, doi:103389/fevo.2017.00069.

Robinson T and Stevenson CM (2017) The cult of the Birdman: religious change at'Orongo, Rapa Nui (Easter Island). Journal of Pacific Archaeology 8: 88-102.

Rull V (2016a) Natural and anthropogenic drivers of cultural change at Easter Island: review and new insights. Quaternary Science Reviews 150: 31-41.

RullV (2016b) The EIRA database: Last Glacial to Holocene radiocarbon ages from Easter Island's sedimentary records. Frontiers in Ecology and Evolution 4: 44, doi: 103389/fevo.2016.00044.

Rull V (2018) Strong fuzzy EHLFS: a general conceptual framework to address past records of environmental, ecological and cultural change. Quaternary 1: 10, doi:103390/quat1020010.

Rull V (2019a) Human discovery and settlement of the remote Easter Island (SE Pacific). Quaternary 2: 15, doi:103390/quat2020015.

Rull V (2019b) The deforestation of Easter Island. Biological Reviews, doi: 10111//brv.12556.

Rull V, Cañellas-Boltà N, Margalef O, Sáez A, Pla-Rabes S and Giralt S (2015) Late Holocene vegetation dynamics and deforestation in Rano Aroi: implications for Easter Island's ecological and cultural history. Quaternary Science Reviews 126: 219-226.

Rull V, Montoya E, Seco I, Cañellas-Boltà N, Giralt S, Margalef O, Pla-Rabes S, D'Andrea W, Bradley R and Sáez A (2018) CLAFS, a holistic climatic-ecological anthropogenic hypothesis on Easter Island's deforestation and cultural change: proposals and testing prospects. Frontiers in Ecology and Evolution 6: 32, doi:103389/fevo.2018.00032.

Seco I, Rull V, Montoya E, Cañellas-Boltà N, Giralt S, Margalef O, Pla-Rabes S, D'Andrea W, Bradley R and Sáez A (2019) A continuous palynological record of forest clearing at Rano Kao (Easter Island, SE Pacific) during the last millennium: preliminary report. Quaternary 2: 22, doi: 103390/quat2020022.

Stevenson CM, Puleston CO, Vitousek PM, Chadwick OA, Haoa S and Ladefoged TN (2015) Variation in Rapa Nui (Easter Island) land use indicates production and population peaks prior to European contact. Proceedings of the National Academy of Sciences USA 112: 1025-1030.

Van Tilburg JA (1994) Easter Island: Archaeology, Ecology, and Culture. Washington: Smithsonian Institution Press.

Wilmshurst JM, Hunt TL, Lipo CP and Anderson AJ (2011) High-precision radiocarbon dating shows recent and rapid initial human colonization of East Polynesia. Proceedings of the National Academy of Sciences USA 108: 1815-1820. 


\section{Figure captions}

1. Location map and example of a moai cluster ( $a h u$ ). A) Topographic sketch map of Easter Island and the sites mentioned in the text. The position of the island on the world map is indicated by a red star. Permanent lakes and marshes are in blue. The location of Orongo $(\mathrm{Og})$ and the Motu Nui islet $(\mathrm{MN})$ are highlighted by red dots. The green dots represent the distribution of present-day moai and $a h u$, according to Van Tilburg (1994). The red lines indicate the westernmost boundary of the studies regarding coastal groundwater seeps by Brosnan et al. (2018) and DiNapoli et al. (2019). B) The moai complex of Ahu Tongariki, which has statues that are up to $9 \mathrm{~m}$ high and 90 tons (see upper panel for location). Photo: N. Cañellas.

2. Summary of climatic and vegetation shifts recorded in continuous and chronologically coherent sediment cores from Rano Aroi (Rull et al., 2015), Rano Kao (Seco e al., 2019) and Rano Raraku (Cañellas-Boltà et al., 2013) sediments using multiproxy paleoecological analyses. Climatic phases according to Nunn (2007). The gray bands represent the droughts recorded at Rano Raraku, during which the lake dried out. Abbreviations: ch - charcoal, as a proxy for fires, cf - spores of coprophilous fungi, as a proxy for domestic herbivores, cu - last cultivation records, pd - partial deforestation, $\mathrm{td}$ - total deforestation. The red arrows indicate possible population movements from Rano Raraku to the other catchments.

3. Lake Kao, within the crater of the same name. The surface of the lake is a mosaic of open water (ca. $10 \mathrm{~m}$ depth) and floating-mat patches of approximately $3 \mathrm{~m}$ depth, which can be walked across. The position of the ceremonial village of Orongo on top of the Rano Kao crest is indicated. The yellow line shows the location of former cultivation terraces documented by paleoecological records (Horrocks et al., 2012, 2013). The photo was taken from the upper part of the pathway used today to descend from the crest of the Rano Kao crater to the lake shore. Photo: V. Rull.

4. Schematic cross-section of a N-S transect showing the hydrological model of Easter Island. Note the progressive thinning of the freshwater table toward the coast. The approximate elevation of Rano Kao and Rano Raraku and the position of Rano Aroi are indicated. Redrawn from Herrera and Custodio (2008). 

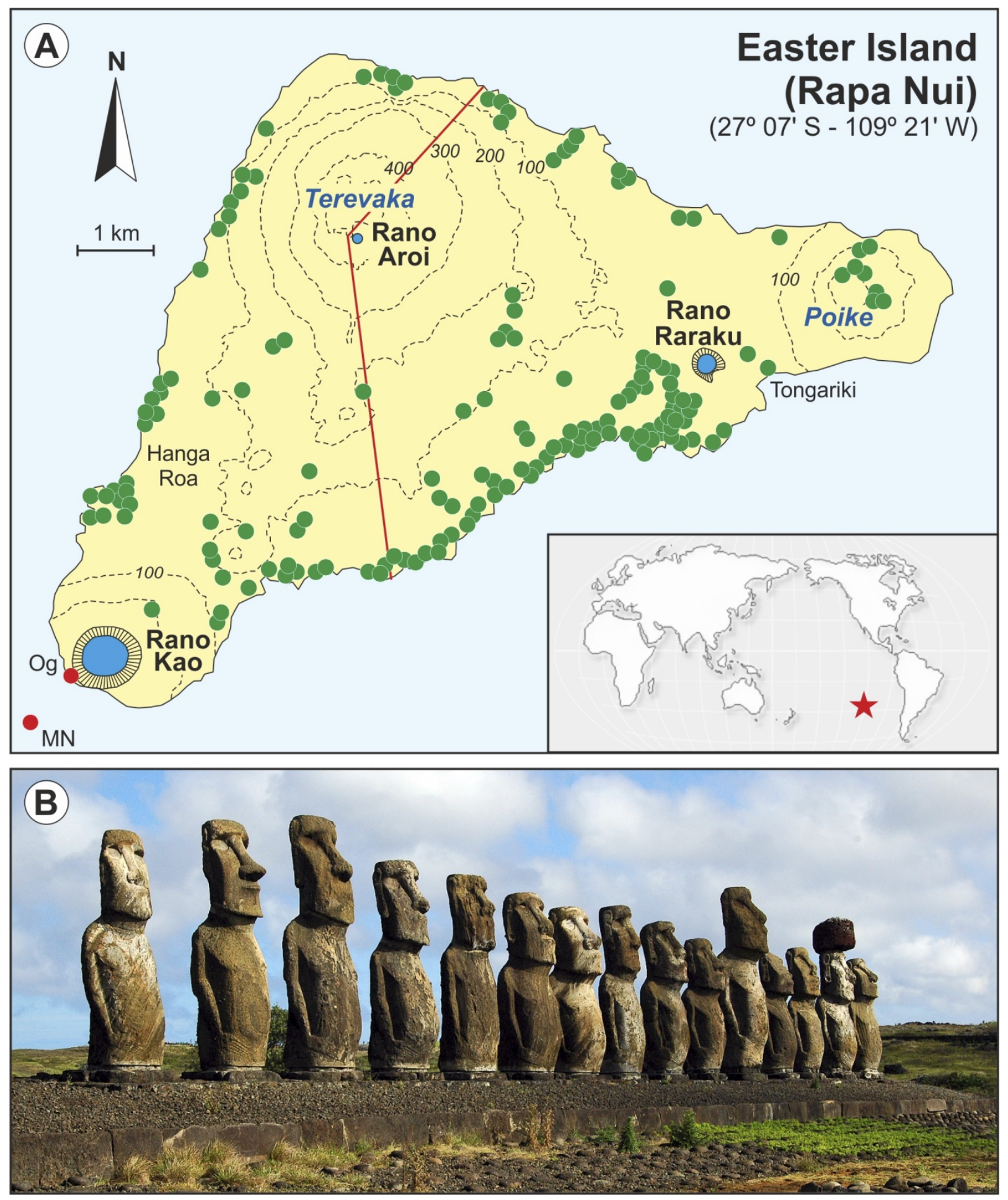

Figure 1 


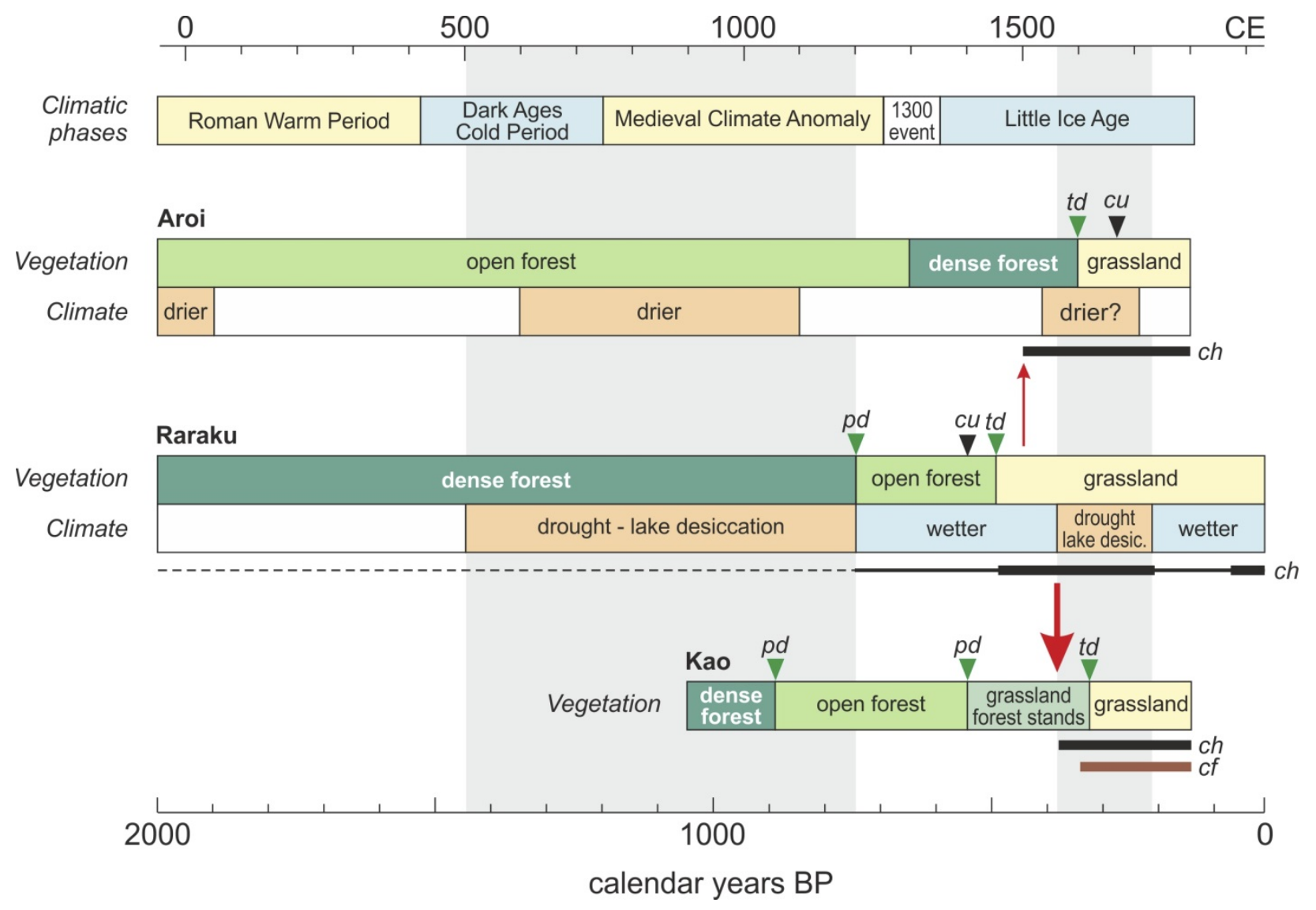

Figure 2 


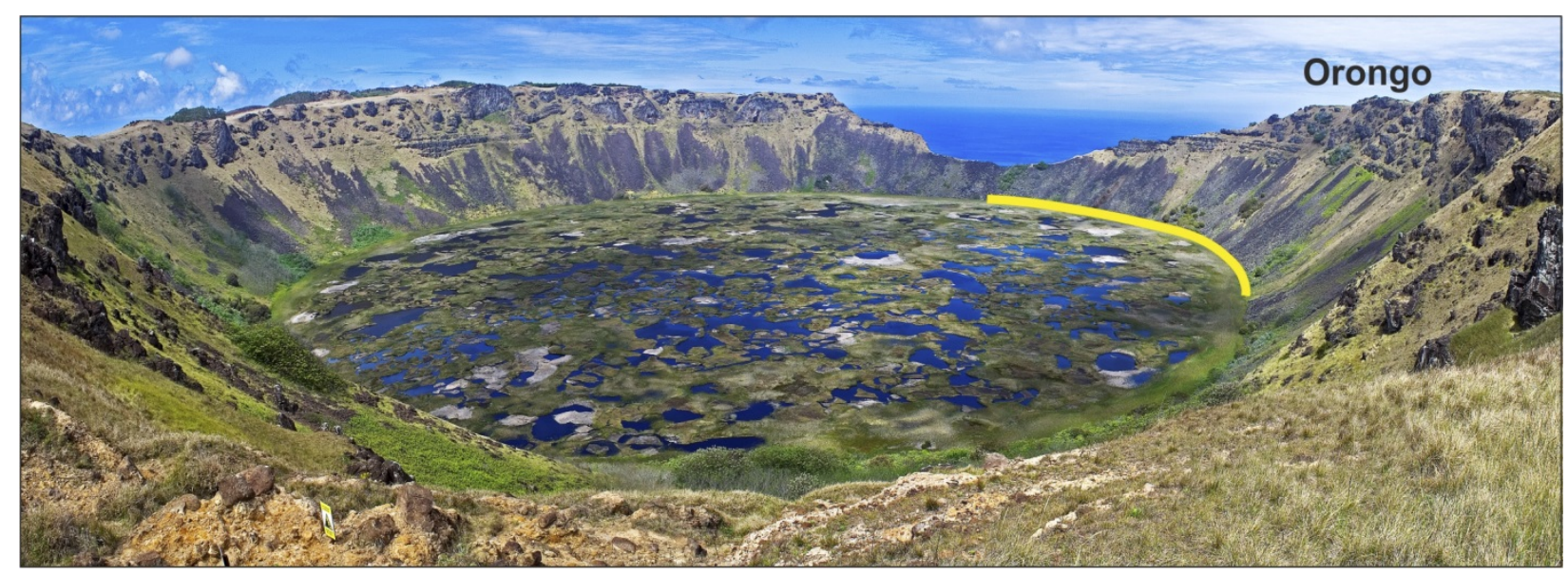

Figure 3

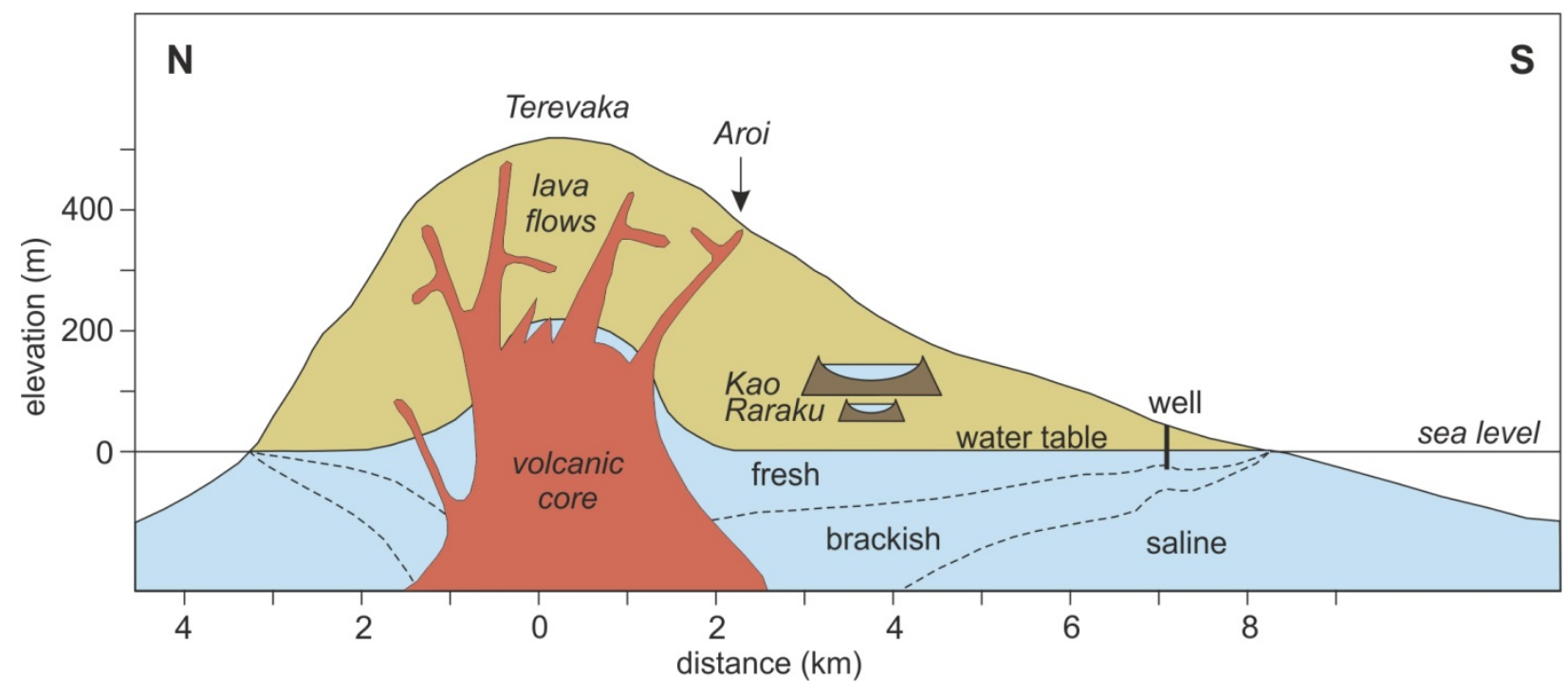

Figure 4 